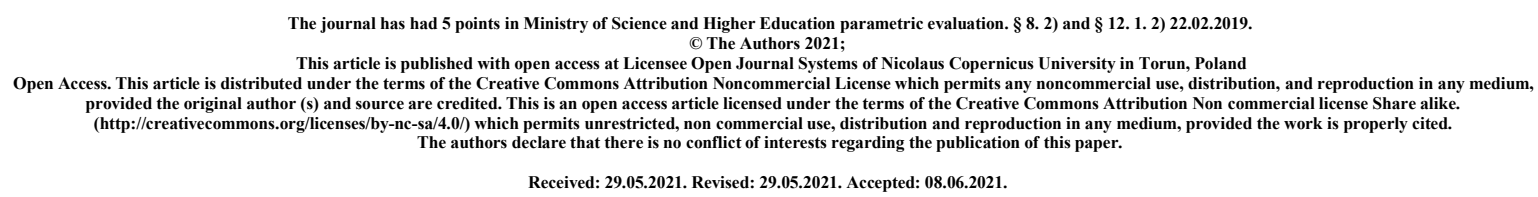

\title{
The benefits of vitamin D3 supplementation for menopausal women - literature review
}

Katarzyna Cyboran katarzyna_cyboran@o2.pl ; Medical Faculty, Institute of Medical Sciences, Collegium Medicum, Oleska Street 48, 45-052 Opole Poland

Monika Kuc - kuc.monika96@gmail.com ; Medical Faculty, Institute of Medical Sciences, Collegium Medicum, Oleska Street 48, 45-052 Opole Poland

Jakub Lis - jlis2607@gmail.com ; Medical Faculty, Institute of Medical Sciences, Collegium Medicum, Oleska Street 48, 45-052 Opole Poland

Damian Machaj damian10b10@o2.pl ; Faculty of Medicine, Medical University of Wroclaw, Wybrzeże L. Pasteura Street 1, 50-367 Wrocław Poland

Jakub Polak - kubap99@op.pl ; Medical University of Silesia; plac Traugutta Street 2, 41-800 Zabrze Poland

\section{ABSTRACT}

Vitamin D represents a common name for cholecalciferol and ergocalciferol. It occurs in the inactive form but as the result of hydroxylation in position 1 or 25 , becomes an active vitamin. Cholecalciferol arises from an inactive form under the influence of UV radiation in the temperature of the human body whereas ergosterol is delivered to the organism from plant-based food. Vitamin D has a significant impact on postmenopausal women's health. The level of estrogen declines for the woman in the menopausal period. It has consequences, among others, of calcium losses. This is the reason why women of this age are in the risk group for come down with osteoporosis. Vitamin D helps with the absorption of calcium and phosphorus. These minerals have an equally important role during the period of menopause. Women in this age group should take from 1000 to $1500 \mathrm{mg}$ of calcium daily. However, 
excessive calcium intake is not recommended, because exceeding the norm does not bring better results. In spite of this fact, the detection of vitamin D deficiency in postmenopausal women and starting treatment has a positive effect on their health. [1]

KEY WORDS: vitamin D, postmenopausal, deficiency

\section{INTRODUCTION AND PURPOSE}

The main goal of this review is to indicate a correlation between the level of vitamin D and the health of postmenopausal women. The patients in this life period often experience symptoms like a frame of mind or hot flashes. [2][3] The effect of this is a significant decline in the quality of life. The usage of hormonal medicines, antidepressants, or anticonvulsants may cause unwanted side effects. [3][4][5] Hence, constantly looking for mechanisms that are responsible for these symptoms is important. Owing to this fact, it would be possible to develop new treatment strategies. [3]

According to the collected data, there is probably a relationship between vitamin $\mathrm{D}$ levels and symptoms in menopause. [3] The activity of the enzyme responsible for the conversion of inactive vitamin D into active vitamin is increased thanks to estrogen. [6]

In the randomized research of Dong and co-authors took part 36,282 postmenopausal women. The patients were supplementing $1 \mathrm{~g}$ of calcium and $10 \mu \mathrm{g}$ of vitamin D. There was no impact to reduce the risk of coronary events and stroke. It has been suggested that the dose was most likely too low. [7]

\section{DESCRIPTION OF THE STATE OF KNOWLEDGE}

Cristina Capatina and co-authors from the University of Bucharest demonstrated in 2014 the effect of evaluation BMD in postmenopausal women. They assessed parameters such as total and ionised calcium, phosphorus, alkaline phosphatase (ALP), 25 hydroxyvitamin D (25OHD), parathyroid hormone (PTH), osteocalcin, beta crosslaps. 


\section{Chart 1}

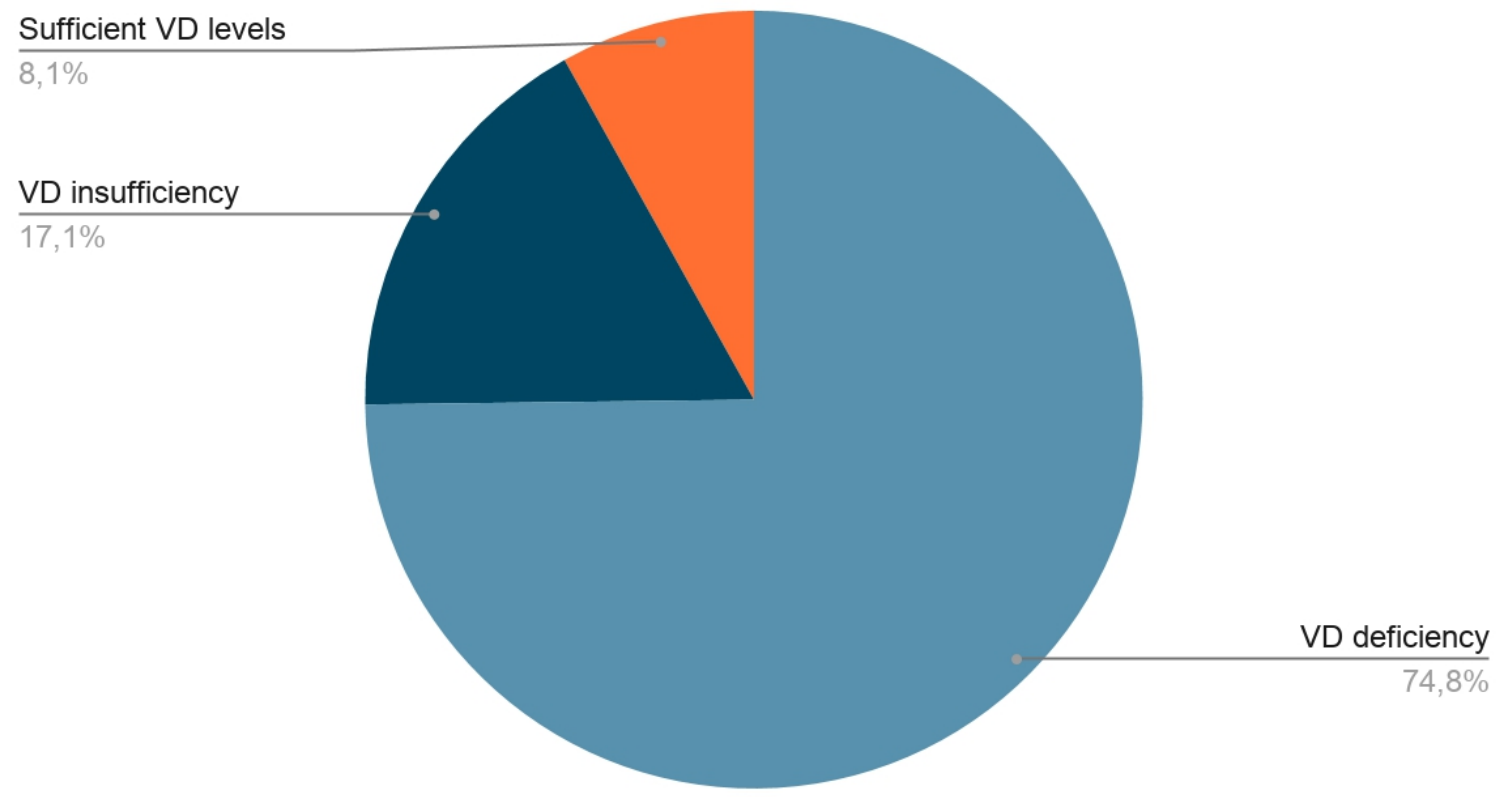

Chart 1 presents that $17.1 \%$ of cases had VD levels insufficiency and $74.8 \%$ had VD deficiency. It means that $91.9 \%$ had $25(\mathrm{OH}) \mathrm{D}$ serum levels below $30 \mathrm{ng} / \mathrm{ml}$. Sufficient VD levels were observed only in $8.1 \%$ of cases. Fragility fractures occurred for $45.83 \%$ of the osteoporotic patients, $27.27 \%$ of the people with osteopenia and the percent for women with normal BMD was $15.15 \%$.

Thirty-two women, which comprise $26 \%$ of evaluated people, were on VD supplementation during the examination. The $25(\mathrm{OH}) \mathrm{D}$ level was considerably higher among these tested persons with earlier fragility fractures $(\mathrm{p}=0.018)$ and osteoporosis $(\mathrm{p}=0.008)$.

The correlation between the concentration of 250HD, PTH, ALP (alkaline phosphatase), and osteocalcin was negative. Significant correlation inverse with the radius BMD, T, and Z scores $(p=0.004)$ was assessed by the bone markers.

For the cases with VD deficiency, $27.17 \%$ of them had secondary hyperparathyroidism and also $250 \mathrm{HD}$ concentration was much lower $(p=0.000)$. [8]

S. Gaugris and co-authors reviewed publications in the past 10 years on the basis of which the incidence of vitamin D deficiency was assessed.

The spread of $25(\mathrm{OH})$ vitamin $\mathrm{D}$ concentration lower than $12 \mathrm{ng} / \mathrm{ml}$ for the osteoporotic group of people was in a range of $12.5-76 \%$. The situation was worse for patients with a cutoff of $15 \mathrm{ng} / \mathrm{ml}$ with fractures in the course of the disease. In this case, the spread reached 50 $70 \%$. Whereas, for the women in the menopausal period spread of $25(\mathrm{OH})$ vitamin $\mathrm{D}$ concentration lower than $20 \mathrm{ng} / \mathrm{ml}$ was in the range of $1.6-86 \%$ accordingly for communityliving and institutionalized women. The main reasons for vitamin D insufficiency are a short 
time of exposure to the sun, especially during winter, a diet low in vitamin D, a nursing home environment, and elderly age (over 70 years). [9]

Navaneethakrishnan Suganthan and co-authors described a study that assessed vitamin D levels in postmenopausal women at the Endocrinology Department of Jaffna Clinical Hospital from January to December 2018. The mean age of examined patients was between 67 and 68 years old. The youngest woman was 38 years old and the oldest, 84. The average concentration of VD was $27.5 \mathrm{ng} / \mathrm{mL}$. The range of concentrations was between 11.7 and 52.5 $\mathrm{ng} / \mathrm{mL}$. The correct levels of vitamin D were only in $36.2 \%$ of cases, insufficiency in $44 \%$ but the deficiency in $19 \%$. In the research participated $20 \%$ vegetarian in which $53 \%$ were consuming milk, $76.2 \%$ fish, and $64.8 \%$ eggs. Moreover, $71.4 \%$ had enough (more than 30 $\mathrm{min}$ /day) sun exposure. People with vitamin D deficiency had symptoms including proximal myopathy - $40 \%$, muscle cramps $-43.8 \%$, malaise $-51.4 \%$, easy fatigability $-54.3 \%$, bonepain $-55.2 \%$ and the most common - paraesthesia - 57.1\%. There was not a significant difference $(\mathrm{P}>0.05)$ in the musculoskeletal symptoms between sufficient, insufficient, and deficient groups. $67.7 \%$ of participants, which equal 71 persons, passed the bone density test, $38 \%$ had osteoporosis. There was a significant correlation with the level of $25(\mathrm{OH}) \mathrm{VD}$ shown by vertebral Z score. [10]

\section{CONCLUSIONS:}

Peri and postmenopausal women are recommened to take vitamin D to prevent bone loss. A VD deficiency especially with a connection with menopause has a negative impact not only to bone health. Both of them have similar risk factors like cardiovascular, metabolic, cognitive and affective disorders. A sufficient vitamin D level may be beneficial to women's health in general. [11]

The women in postmenopausal period have a higher risk of osteoporosis, cardiovascular disease and breast cancer. A VD has a protective impact againsts cardiovascular risks, breast neoplasm and bone health. Knowledge of vitamin D properties can widen comprehension of pathophysiology of chronic conditions. Vitamin D screening supplementation, and obviously teaching the patients about preventing debilitating conditions among postmenopausal women should be provided by primary care physicians. [12]

\section{LIST OF REFERENCES:}

1. Piotr Gajewski, Andrzej Szczeklik; Interna Szczeklika 2017 Podręcznik chorób wewnętrznych

2. Simon JA, Reape KZ. Understanding the menopausal experiences of professional women. Menopause. 2009 Jan;16(1):73-6. [PubMed] [Google Scholar] 
3. Erin S. LeBlanc, MD, MPH, Manisha Desai, PhD, Nancy Perrin, PhD, Jean Wactawski-Wende, PhD, JoAnn E. Manson, MD, DrPH, Jane A. Cauley, DrPH, Yvonne L. Michael, ScD, Jean Tang, MD, PhD, Catherine Womack, MD, Yiqing Song, MD, ScD, Karen C. Johnson, MD, MPH, Mary J. O’Sullivan, MD, Nancy Woods, PhD, RN, FAAN, and Marcia L. Stefanick, PhD Vitamin D levels and menopause-related symptoms Menopause. Author manuscript; available in PMC 2016 Feb 23. Published in final edited form as: Menopause. 2014 Nov; 21(11): 1197-1203.

4. Park MK, Satoh N, Kumashiro M. Wpływ uderzeń gorąca w okresie menopauzy na obciążenie psychiczne. Ind Health. 1 sierpnia 2011; [ PubMed ] [ Google Scholar ]

5. Geukes M, van Aalst MP, Nauta MC, Oosterhof H. Wpływ objawów menopauzy na zdolność do pracy. Klimakterium. 2012 Mar; 19 (3): 278-82. [ PubMed ] [ Google Scholar]

6. Buchanan JR, Santen R, Cauffman S, Cavaliere A, Greer RB, Demers LM. Wpływ wahań endogennego estrogenu na metabolizm 25-hydroksywitaminy D. Calcif Tissue Int. 1986 wrzesień; 39 (3): 139-44. [ PubMed ] [ Google Scholar]

7. J. Dong, SL Wong, CW Lau, $i$ in. Kalcytriol przywraca funkcję naczyniowonerkową u szczurów $\mathrm{z}$ niedoborem estrogenu poprzez regulację $\mathrm{W}$ dół cyklooksygenazy-2 i receptora tromboksanowo-prostanoidowego; Kidney Int , 84 ( 2013 ), ss. $54-63$

8. Cristina Capatina, Mara Carsote, Andra Caragheorgheopol, Catalina Poiana, And Mihai Berteanu - Vitamin D Deficiency in Postmenopausal Women - Biological Correlates, Maedica (Bucur). 2014 Dec; 9(4): 316-322.

9. S. Gaugris, R.P. Heaney, S. Boonen, H. Kurth, J.D. Bentkover, S.S. Sen; Vitamin D inadequacy among post-menopausal women: a systematic review; QJM: An International Journal of Medicine, Volume 98, Issue 9, September 2005, Pages 667676 ,

10. Navaneethakrishnan Suganthan, Thirunavukarasu Kumanan, Vithegi Kesavan, Mahalingam Aravinthan \& Nadarajah Rajeshkannan; Vitamin D status among postmenopausal osteoporotic women: a hospital based cross-sectional study from Northern Sri Lanka; BMC Nutrition 6, Article number: 15 (2020)

11. Elisabeth Lerchbaum; Viamin D and menopause - A narrative review; Maturitas, Volume 79, Issue 1, P3-7, September 01, 2014

12. Lesia Aungs tMSN, FNP Sharon Rainer MSN, CRNP; Importance of Vitamin D to Postmenopausal Women's Health; The Journal for Nurse Practitioners Volume 10, Issue 9, October 2014, Pages 653-659 